І. В. Існюк, аспірант

(Житомирський державний університет імені Івана Франка) inna_harutykeukr.net ORCID: $000 \overline{0}-0001-8885-1835$

\title{
ТЕНДЕНЦІЇ РОЗВИТКУ ЕСТЕТОСФЕРИ Й ХУДОЖНЬОГО ПРОСТОРУ СУЧАСНОГО СОЦУМУ: ФОРМОТВОРЧІ НОВАЦІЇ ТА ЇХ КОНЦЕПТУАЛЬНЕ ПІДІРУНТЯ
}

У статті проаналізовано тендениії розвитку естетосфери та художнього простору сучасного соиіуму та глибинні чинники, які характеризують їх взаємодію, зокрема тенденцію до самовираження мития через новітні форми творчості. Розглянуто феномен художнього простору, щчо містить в собі певні естетичні елементи та фактори сучасності, а також його роль в сочіокультурному житті. Також завдяки проведеному аналізу специфіки сучасного мистецтва указано вплив таких новацій на естетосферу та культурне життя суспільства.

Завдяки цььому поглиблено розуміння естетичних смаків і ичінностей, поглядів та естетичних ідеалів в нашу епоху.

Ключові слова: естетосфера, естетичний досвід, естетика ницого, художнє мислення, художній простір, художній образ.

Постановка проблеми дослідження. Поглиблення уявлень про значення естетичних моментів у житті сучасної людини і змістового наповнення поняття естетосфери, в контексті розвитку естетичної теорії, зумовлено тенденцією у соціумі XXI століття, з одного боку, до прагнення багатьох сучасників до естетизації побуту й повсякденності, а, з іншого, зростання кількості тих, хто займається мистецтвом як аматор. Крім того, фіксується й феномен прагнення до опертя на художню діяльність, коли виникає не твір мистецтва у класичному його розумінні, а художня інновація іншого плану. Митцям властиво прагнути в такий чи інший спосіб виразити у творчому здобутку певні естетичні ідеали та цінності людського буття своєї епохи. Але не кожний зразок сучасної художньої діяльності демонструє опертя на них. Тому цілісне уявлення про соціокультурне життя суспільства можна сформувати при зверненні до аналізу естетосфери та художнього простору сучасності. Переживання і прагнення до кращого майбутнього тісно пов'язані із естетичним досвідом, який, 3 одного боку, $є$ набутим самостійно людиною, а 3 іншого - шляхом пізнання історичних здобутків. До переосмислення дійсності нас спонукають, передусім, досконалі художні образи, які виникають шляхом формотворчих пошуків митців. Але варто наголосити, що прогрес і в техніці, і в науці нині впливають на темп життя і цінності суспільства в цілому. Звідси маємо не що інше, як феномен художнього простору із низкою інновацій як подразників для сучасника, що сприяє пошукам на основі художньої діяльності нових формотворчих способів вираження духовних запитів соціуму, його соціокультурного життя через призму повсякденності. І не завжди зразки такої діяльності утримують в собі естетичне начало.

Аналіз останніх досліджень і публікацій свідчить про те, що естетосфера соціуму формується під впливом різнорідних чинників та є простором для реалізації людством естетичних ідеалів та ціннісних орієнтирів. Варто відмітити, що феномен естетосфери досліджувався С. Василенком, М. Каганом, Н. Левченко, А. Пригорницькою (насамперед при зверненні до естетосфери сучасного дизайну), численні праці присвячені розгляду естетосфери українським естетиком В. Личковахом, в осмисленні релігійно мистецьких практик висвітлені дослідником А. Царенок; у галузі правової естетики - А. Романовою та ін. Так, досліджуючи історію вивчення естетосфери, А. Царенок стверджує, що нижче зазначені ії тлумачення постають взаємодоповнюючими та вказують на багатоаспектність підгрунтя даного явища. За результатами розвідки автор вказує на неоднозначність його розуміння, а саме: естетосфера визначається як естетичне в цілому явище (С. Василенко), як світ естетичних цінностей (М. Каган, Н. Левченко) чи як цілісна сукупність "емотивних і візуальних вимірів всіх емоційно-виразних феноменів життя, культури і мистецтва" [1: 48]. Треба вказати, що такі підходи є відмінними, і це засвідчує як складність явища, так і не достатнє опрацювання проблеми природи і складників естетичних моментів життя соціуму не на індивідуальному рівні, а у вимірі загальнолюдського значення в умовах новітніх викликів.

Метою даної розвідки $є$ аналіз та опис формотворчих новацій теперішнього суспільства, що дає змогу висвітлити тенденції розвитку естетосфери та художнього простору, в їх взаємодії у контексті соціокультурного життя і запитів багатьох сучасників. Очевидним є те, що художній образ виникає не лише через індивідуальне прагнення чи реалізацію потреб митців, а як віддзеркалення людського буття 3 його естетичними цінностями та ідеалами, які є актуальними для даної епохи, на тлі існування реалій художнього життя і художньої діяльності. 
Виклад основного матеріалу. Існує не мало спонукань до зацікавлення сучасним художнім простором, в якому не лише митці створюють різні твори мистецтва, а й є перформанси, інсталяції тощо. За І. Бондаревською [2], особистість усвідомлює оточення та власне буття у розвиненому й наповненому перспектив соціокультурному світі при невідповідності наявній естетичній теорії реальних естетичних цінностей, естетичних смаків та ідеалів теперішньої людини. Тому розуміння духовних потреб соціуму вимагає для дослідників розкривати низку питань і наукових проблем у галузі естетики та образотворчого мистецтва. Український естетик В. Личковах досліджуючи естетосферу, розглядає їі два виміри в епосі авангардизму. Загалом під естетосферою він розуміє "цілісну сукупність духовночуттєвих (емотивних) і образних (візуальних) вимірів всіх емоційно-виразних феноменів життя, культури і мистецтва, аксіосфери суспільства" [3: 4]. Проте варто вказати, що аналіз візуальності, наразі, виглядає дещо збіднюючим реальність такого елемента духовного життя суспільства. Досліджуючи феномен естетичного споглядання Ю. Юхимик [4: 68] також акцентує увагу на різноманітних чинниках, які впливають на формування естетосфери сучасності. На iі думку, такими чинниками є, окрім політикоекономічного чинника, прискорений темп життя та діяльнісна активність суспільства. Такі умови спричиняють недостатність зосередження на естетичних якостях предметного оточення і характеризують естетосферу з низкою естетичних подразників. Зокрема автор статті наголошує на "відстороненості від формального розмаїття реальних життєвих явищ" [4: 69], спричиненою не чим іншим, як тенденцією буття у сучасному "віртуальному" світі. Зазначимо, що дослідницею Л. Усіковою вжито поняття естетосфери при аналізі естетичних процесів соціуму (на прикладі розгляду естетичних основ ісихазму доби Київської Русі) [5]. Нею проаналізовано вплив на естетосферу тогочасного суспільства християнських поглядів та указано на проникнення в філософію, мистецтво й естетичну думку Київської Русі естетичних ідей ісихазму як "естетики аскетизму", що вплинула на специфіку художнього мислення тогочасних митців (В. Бичков) та особливості їхнього прагнення до синтезу мистецтв тощо.

Нашу увагу привертає естетичне підгрунтя естетосфери сучасного соціуму на прикладі метафоричності художніх образів митців, а саме: його формотворчі фактори та естетичне вираження досконалого художнього образу. Такі незвичні об'єкти колумбійського художника Федеріко Урібе (Federico Uribe) варто назвати шедевром, адже автор тонко зумів передати гнучкість диких тварин, правдоподібність їх форм та розмірів, гру кольорів й відтінків при створенні пейзажів тощо. Але митець створює скульптури і картини із гільз, клавіш піаніно, кольорових олівців, сторінок книг та інших предметів побуту і щоденного вжитку. Купуючи гільзи в металопереробній компанії, автор "намагається створити красу із символів смерті" [6]. Адже, за його словами, використовуваний ним матеріал несе в собі далеко не позитивні спогади, але, з іншого боку, а чому б і не спробувати поекспериментувати 3 ним? Тому Ф. Урібе вважає, що красу треба зуміти побачити всюди, а саме в тих елементах, які можуть асоціюватися, а в нашому випадку й асоціюються, навіть мають пряме до того відношення, із низьким і трагічним. Тут він ніби підкреслює зв'язок між "естетикою ницого" та красою. Своєрідний життєвий досвід (виріс у країні, де безупинно тривали воєнні дії, але зараз мешкає у Флориді) спонукає колумбійського митця до переосмислення й відображення теми смерті у художній діяльності, що дає йому можливість і до самовираження, і до власного відчуття гордості і бути відомим. Адже "художник, як і кожна людина, має свої світоглядні переконання, моральні та естетичні ідеали, політичні уподобання тощо" [2: 675]. Вражаючі праці автора, або "колекція із пуль" [6] для одного реципієнта є нагадуванням про жахіття війни й несе в собі ідею ницого (панцирі черепах із касок воїнів), а для іншого - нагадування про полювання (дикі птахи чи пес, який допомагає у полюванні), ще для інших - це проблема зникаючих видів тварин (хто переймається проблемою екології). Відтак зазначимо, що художні інновації Ф. Урібе знаходять відгук у різних прошарках сучасного суспільства та є середовищем для художнього досвіду, в якому знаходимо поєднання ідеї ницого, естетики прекрасного, насамперед, та комічного, в деякій мірі. Але вони відходять, на наш погляд, від цінності ідеї калокагатії для митця, і ніби привчають до ідеї "позитивів війни", їх гуманна суть тому є дискусійною. Це приклад, як видається, елемента художнього простору.

В американського митця із Каліфорнії Ендрю Майєрса (Andrew Myers) маємо синтез живопису в реалістичній манері із площинною скульптурою (барельєфом). Таку незвичну техніку (ідея застосовувати шурупи при створенні картин) Е. Майєрс спробував втілити у життя i, завдяки чому, зумів здобути собі славу художника і скульптора. Адже це, перш за все, була така собі розвага [7] між друзямихудожниками у студентські роки - придумати цікаві, незвичні і нові речі. "Гра" із гвинтиками спонукала до створення малюнку дюймового рельєфу із різною висотою на глині або бронзі. Вкажемо, що у планах митця - створення картини, на якій буде зображена людина у повному своєму зрості. Зважаючи на те як реалістично та натурально виглядають його теперішні художні образи, можна стверджувати, що майбутня праця буде не менш цікавою і привабливою за попередні. Варто вказати, що не $є$ легким завданням у портреті підкреслити риси обличчя, їх витонченість або навпаки, використовуючи такий матеріал (шурупи). Але завдяки поєднанню зображальних і виражальних засобів для створення 
художнього образу такий твір мистецтва дає можливість відчути глядачеві задоволення від побаченого, i він має гуманний сенс.

А от Куін Шим (Kyuin Shim) намагається не тільки створити у своїй уяві нетипові скульптури, а й зуміти донести їх до споглядача свого мистецтва [8]. К. Шим - талановитий цифровий художник із Кореї, мистецькі роботи якого досить незвичайні, бо створює не просто красиві ілюстрації або картини, а справжні цифрові скульптури. Він, звернемо увагу, робить твори, які з першого погляду можуть здатися професійними фотографіями робіт якогось скульптора-сюрреаліста. Чому ніби малює? Бо скульптур як таких не існує, вони створені, перш за все, в його уяві і на малюнках. Незвичне поєднання живопису, фотографії та мистецтва об'ємних (цифрових) художніх форм у реальному просторі (скульптури). К. Шим здебільшого створює свої зображення в монохромному або чорно-білому вигляді 3 метою зосередження уваги реципієнта на скульптурі, іiі витонченості та чуттєвості, тонкому філософському підтексті, глибинності смислів та естетичних цінностей. Адже митець, на основі власного життєвого та естетичного досвіду, намагається висловити у цих цифрових скульптурах внутрішній стан особистості 3 емоційною пригніченістю, душевними переживаннями. Проте художні образи у "нереальному просторі" передають любов, людські відносини з емоційно-чуттєвою виразністю. Укажемо, що таке своєрідне візуальне мистецтво створене на основі новітніх технологій та пропагує цінність гармонії, ідеалу прекрасного, як однієї з основних категорій естетики. Однак матеріали використані дуже незвичні.

Варто згадати й про такого художника-пірографа як Джордан Манг Осан (Jordan Mang-Osan), який створює картини за допомогою полотна, лупи і сонячного світла [9]. Такого ефекту, який передають його картини, не досягти за допомогою традиційних художніх інструментів: пензлика чи олівців тощо. Як зрозуміло, важливу роль у створенні таких творів мистецтва художником відіграє природний компонент - сонце, а саме: його промені. Митець, укажемо, орієнтується на "естетику штучних форм", створюючи "картини сонця" й обираючи незвичний інструмент для створення художніх образів: малюючи портрети і пейзажі з рисовими терасами. Знаходячи цікаві сюжети в навколишньому середовищі, він створює твори, утім, через звернення до естетичного ідеалу прекрасного. Це приклад, на наш погляд, ще одного елемента сучасної естетосфери.

Зауважимо, що створені митцями шляхом формотворчих пошуків художні образи, як наголошує український естетик О. Поліщук, "мають й мали різні сфери побутування, ступінь поширення. I їх (мистецьких інновацій) образна структура також не однакова. Композиційний, виражальний i зображальний аспекти твору мистецтва мають різне значення у різних мистецтвах" [10: 113]. I ще треба враховувати, що в їхньому художньому мисленні "утилітарний і "розважальний", ігровий моменти представлені по-різному..." [10: 88]. Митець при формотворчих пошуках спирається не завжди на художньо-образне мислення, якому властиве "породження художнього образу чи їх системи, що в кожному конкретному випадку (в залежності від виду мистецтва) набувають своєрідної знакової фіксації" [10: 100] та у якого сферою "побутування визнається мистецька практика" [10: 89]. Йому притаманне прагнення розваги, як "специфічна "гра" зі смислом, значенням предметної форми або композиції, умоосяжного образу чи символу, і власною експресією чи емоційно-почуттєвими станами того, хто буде співучасником до його процесу або результатів" [10: 100], - вказує О. Поліщук. Але в наш час не завжди митець породжує інновацію із гуманним сенсом, як хочемо наголосити, адже людина при формотворчому пошуку робить новацію "або на засадах гармонії, або дисгармонії, в залежності від того яка вона внутрішньо" [10: 108]. Тоді його виріб виникає через художню творчість, але чи він є елементом естетосфери? Крім того, треба враховувати, що зараз виникли практики, для яких важливе естетичне начало, але вони не є мистецтвом, наприклад дизайн. Відтак іноді для людини, як наголошує науковець, може стати важливішим "художньо-проектне або дизайн-мислення" [10: 100]. Це має місце в архітектурі, наприклад, звернемо увагу також, що на відміну від митця, що втілює своє бачення світу на основі ідеалів класичного мистецтва, фуд-стиліст Кася Гаупт (Kasia Haupt) створила і веде блог "Сендвічмонстри" (Sandwich Monster) [11]. Авторкою "ненудних бутербродів" (із звичайних продуктів для приготування сніданку) є жителька Нью-Йорку. Її "картини" викликають усмішку на обличчі та дивують своєю простотою (як легко зробити із шинки крила летючої миші чи зуби злодія із жовтого твердого сиру), мають комічний характер й розвивають уяву. Адже окремі персонажі є для глядачів відомими, а деякі К. Гаупт вигадує сама. Тобто, при створенні таких зразків художньої діяльності спостерігаємо використання незвичних матеріалів, i, крім того, - своєрідне поєднання кулінарії та досвіду прикладного мистецтва, спираючись зокрема на ідеал комічного. Тут маємо приклад художньої діяльності, результати котрої теж постають елементами художнього простору сучасного суспільства, але не його естетосфери, як видається.

Висновки із дослідження й перспективи подальших розвідок у цьому напрямі. Естетична діяльність людства спрямована, насамперед, на пошук і створення краси, як нової довершеної форми, особливого - художнього образу. Але, у зв'язку зі зміною духовних запитів сучасників через нудьгу й бажання новизни, формотворчі новації не завжди мають чітко окреслені форми чи техніки їх створення, а також гуманістичний сенс. Взяти до прикладу картину із круп і різних видів "сипучих" матеріалів 
(гречка, рис, макаронні вироби, насіння різних видів тощо), що розмиваються межі між декоративноприкладним мистецтвом та живописом. Чи ж "їстівні" художні новації, які не є зразком творів класичного "високого" мистецтва і не створені митцем, і мають прикладний характер, пов'язаний із гастрономією та гурманством. Проте це й свідчення затребуваності естетизації побуту у мешканців Європи або їхнього прагнення до розваги завдяки художній діяльності. Хоча можливо глибинні чинники полягають у прагненні багатьох людей до самовираження, зокрема в художній творчості, навіть при відсутності спеціальної художньої освіти? Чи може мода на гру й соціальне навіювання через 3МІ постає причиною таких формотворчих пошуків у художній діяльності "аматорів від мистецтва"? Чи в умовах досить терпимого ставлення до художнього пошуку митці в творчості прагнуть експериментів? 3’ясування витоків подібного може складати перспективу подальших досліджень.

\section{СПИСОК ВИКОРИСТАНИХ ДЖЕРЕЛ ТА ЛІТЕРАТУРИ}

1. Царенок А. В. Естетосфера риторичного мистецтва (на прикладі православної проповіді в Україні) : дис. ... канд. філос. наук : 09.00.08 / Царенок Андрій Вікторович ; КНУТШ. - Київ, 2012. - С. 40-49.

2. Isniuk I. Praca ukraińskiej artystki Darii Marczenko "Oblicze wojny" jako odpowiedź na rosyjsko-ukraiński konflikt wojenny / I. Isniuk // W : Wojna / pokój. Humanistyka wobec wyzwań współczesności : [monografia naukowa] / red. Roman Sapeńko, Piotr Pochyły. - Zielona Góra : Uniwersytet Zielonogórski, 2017. - S. 673-688.

3. Личковах В. А. Естетосфера авангардизму / В. А. Личковах // Вісник Черкаського університету. - Серія : Філософія. Вип. 170. - Черкаси : ЧНУ імені Богдана Хмельницького, 2009. - С. 4-16.

4. Юхимик Ю. Естетичне споглядання: сутність та модерні трансформації / Ю. Юхимик // [філософія] Людинознавчі студії. - Вип. 28. - 2013. - С. 61-72.

5. Усікова Л. С. Естетичні транспозиції ісихазму в мистецтві Київської Русі : автореферат дис. ...канд. філософ. наук : 09.00.08 / Л. С. Усікова ; МОН України. - Київ : Вид-во НПУ імені М. П. Драгоманова, 2016. $-19 \mathrm{c}$.

6. Художник Федерико Урибе делает скульптуры и картины ... из пуль [Электронный ресурс]. - Режим доступа : https://www.youtube.com/watch?v=TUT-ShzC3Ho.

7. Американець Ендрю Майєрс застосовує шурупи для створення своїх картин [Електронний ресурс]. - Режим доступу : http://ukraineartnews.com/news/news/amerikanets-endrju-majjers-zastosovuje-shurupi-dlja-stvorennjasvojih-kartin.

8. Корейський художник Куін Шим створює дивовижні цифрові скульптури [Електронний ресурс]. - Режим доступу : http://ukraineartnews.com/news/inframe/korejskij-hudozhnik-kuin-shim-stvorjuje-divovizhni-tsifroviskulpturi.

9. Художник Джордан Мангосан создает картины с помощью обычной лупы и солнечного света [Электронный ресурс]. - Режим доступа : http://www.artinheart.ru/post/people/1830.shtml.

10. Поліщук О.П. Художне мислення: естетико-культурологічний дискурс : [монографія] / О.П. Поліщук. - К. : Вид. ПАРАПАН, 2007. - 208 с.

11. I їсти шкода : талановитий художник створює няшних монстриків із простого хліба [Електронний ресурс]. Режим доступу : https://lux.fm/i-yisti-shkoda-talanovitij-hudozhnik-stvoryuye-nyashnih-monstrikiv-iz-prostogohliba_n73931.

\section{REFERENCES (TRANSLATED \& TRANSLITERATED)}

1. Tsarenok A. V. Estetosfera rytorychnoho mystetstva (na prykladi pravoslavnoi propovidi v Ukraini) [Estethoshere of Rhetorical Art (on the Example of Orthodox Sermon in Ukraine)] : dys. ... kand. filos. nauk : 09.00.08 / Tsarenok Andrii Viktorovych ; KNUTSH. - Kyiv, 2012. - S. 40-49.

2. Isniuk I. Praca ukraińskiej artystki Darii Marczenko "Oblicze wojny" jako odpowiedź na rosyjsko-ukraiński konflikt wojenny / I. Isniuk // W : Wojna / pokój. Humanistyka wobec wyzwań współczesności : [monografia naukowa] / red. Roman Sapeńko, Piotr Pochyły. - Zielona Góra : Uniwersytet Zielonogórski, 2017. - S. 673-688.

3. Lychkovakh V.A. Estetosfera avanhardyzmu [Estethoshere of Avant-Garde] / V. A. Lychkovakh // Visnyk Cherkas'koho universytetu [Cherkasy University Journal]. - Seriia : Filosofiia. - Vyp. 170. - Cherkasy : CHNU imeni Bohdana Khmel'nyts'koho, 2009. - S. 4-16.

4. Yukhymyk Yu. Estetychne spohlyadannia: sutnist' ta moderni transformatsiyi / Yu. Yukhymyk // [filosofiya] Lyudynoznavchi studii [Human Studies]. - Vypusk 28. - 2013. - S. 61-72.

5. Usikova L. S. Estetychni transpozytsii isykhazmu v mystetstvi Kyivs'koi Rusi [Aesthetic Transpositions of Isihasm in the Art of Kyivska Rus] : avtoref. dys. ...kand. filosof. nauk: 09.00.08 / L. S. Usikova ; nauk. ker. V. A. Lychkovakh ; M-vo osvity i nauky Ukrainy. - Vyd-vo NPU imeni M. P. Drahomanova, 2016. - 19 s.

6. Khudozhnik Federiko Uribe delaiet skul'ptury i kartiny ... iz pul' [The Artist Federico Uribe Makes Sculptures and Paintings ... from Bullets] [Elektronnyi resurs]. - Rezhym dostupa : https://www.youtube.com/watch?v=TUTShzC3Ho.

7. Amerykanets' Endryu Mayers zastosovuie shurupy dlia stvorennia svoikh kartyn / Elektronnyy resurs. - Rezhym dostupu: http://ukraineartnews.com/news/news/amerikanets-endrju-majjers-zastosovuje-shurupi-dlja-stvorennjasvojih-kartin.

8. Koreys'kyi khudozhnyk Kuin Shym stvoriuie dyvovyzhni tsyfrovi skul'ptury [Korean Artist Kuin Shim Creates Amazing Digital Sculptures] [Elektronnyi resurs]. - Rezhym dostupu : http://ukraineartnews.com/news/inframe/korejskij-hudozhnik-kuin-shim-stvorjuje-divovizhni-tsifrovi-skulpturi. 
9. Khudozhnik Dzhordan Mangosan sozdaiet kartiny s pomoshchiu obychnoi lupy i solnechnogo sveta [The Artist, Jordan Mangosan, Creates Paintings Using a Conventional Magnifier and Sunlight] [Elektronnyi resurs]. - Rezhym dostupa : http://www.artinheart.ru/post/people/1830.shtml.

10. Polishchuk O. P. Khudozhnie myslennia : estetyko-kul'turolohichnyi dyskurs [Artistic Thinking: Aesthetic and Cultural ] : [monohrafiia] / O. P. Polishchuk. - K. : Vyd. PARAPAN, 2007. - 208 s.

11. I yisty shkoda : talanovytyi khudozhnyk stvoriuie niashnykh monstrykiv iz prostoho khliba [And It's a Pity: a Talented Artist Creates Nude Monsters from Simple Bread] [Elektronnyi resurs]. - Rezhym dostupu : https://lux.fm/i-yisti-shkoda-talanovitij-hudozhnik-stvoryuye-nyashnih-monstrikiv-iz-prostogo-hliba_n73931.

\section{Иснюк И. В. Тенденции развития эстетосферы и художественного пространства современного социума: формообразующие новации и их концептуальная почва.}

В статье проанализированы тенденщии развития эстетосферы и художественного пространства современного соииума и глубинные факторы, которые характеризуют их взаимодействие, в частности, тенденция к самовыражению художника посредством новейших форм творчества. Рассмотрено феномен художественного пространства, содержащего в себе определенные эстетические элементы и факторы современности, а также его роль в социокультурной жизни. Также благодаря проведенному анализу специцики современного искусства указано влияние таких новаций на эстетосферу $и$ культурную жизнь общества, и углубленно понимание роли эстетических вкусов и цееноостей, взглядов и эстетических идеалов в нашу эпоху.

Ключевые слова: эстетосфера, эстетический опыт, эстетика низменного, художественное пространство, художественное мышление, художественный образ.

\section{Isniuk I. V. Trends in the Development of the Aesthetosphere and Artistic Space in Modern Society: Formatological Innovations and Their Conceptual Background.}

The article analyzes tendencies in the development of the aesthetic sphere and artistic space in modern society and the factors that characterize it, in particular, the tendency to self-expression of the artist through the latest forms of creativity are underlined.

The deepening of the essence of the notion of aestethosphere in the 21st century society is due to its tendency to isolate and strive for the aesthetizing of everyday life. Artists are always apt in one way or another to express the likelihood of aesthetic ideals and the value of human existence of this era. A holistic ratio of socio-cultural life takes place in the aesthetic and artistic space of our days, which contains certain aesthetic elements and factors

of the present, thus deepening the understanding of aesthetic tastes, values, views and aesthetic ideals of a certain era, as well as their role in socio-cultural life. Also, due to the analysis of the specifics of contemporary art, the form-making innovations of the aesthetics and the cultural life of society in the contemporary sociocultural context have been discovered. The activity of humanity is aimed at finding and creating beauty and a new perfect form, a special artistic image. However in connection with the change in the spiritual demands of contemporaries due to boredom and the desire for novelty, form-making innovations do not have clearly defined forms or techniques of their creation.

Key words: aesthetosphere, aesthetic experience, lowland aesthetics, artistic space, artistic thinking, artistic image. 